\title{
KARAKTERISTIK PETANI KELAPA SAWIT DI NAGARI AIR HITAM KECAMATAN SILAUT KABUPATEN PESISIR SELATAN
}

\author{
Yuliawati $^{1}$, Rahmanelli ${ }^{2}$ Khairani $^{2}$ \\ Program Studi Pendidikan Geografi \\ Fakultas Ilmu Sosial, Universitas Negeri Padang \\ Email:yuliawati9624@gmail.com
}

\begin{abstract}
Abstrak
Tujuan dari penelitian ini adalah untuk mengetahui karakteristik petani kelapa sawit di Nagari Air Hitam Kecamatan Silaut Kabupaten Pesisir Selatan.Jenis penelitian ini adalah penelitian kuantitatif.Populasi dan sampel dalam penelitian ini adalah petani kelapa sawit di Nagari Air Hitam Kecamatan Silaut Kabupaten Pesisir Selatan.Pengumpulan data dilakukan melalui observasi dan angket.Data hasil penelitian dianalisis menggunakan rumus persentase dan skala likert.Hasil penelitian ini memperlihatkan bahwa: (1) Rata-rata luas lahan petani kelapa sawit adalah 0,5-2 hektar. (2) Rata-rata lama usaha petani kelapa sawit antara 5-10 tahun. (3) Intensitas penyuluhan sangat rendah. (4) Pemanfaatan sumber informasi untuk menambah pengetahuan sangat rendah, manfaat sumber informasi terbaru sangat rendah, dan pihak yang memberikan informasi juga sangat rendah. (5) Petani tidak melakukan pemupukan secara rutin. (6) Rata-rata petani menggunakan pestisida dua liter per hektar, jenis pestisida yang digunakan adalah gramason, rata-rata petani menggunakan pestisida dua kali dalam setahun.
\end{abstract}

Kata Kunci : Karakteristik PetaniKelapa Sawit

\begin{abstract}
This study is aimed at knowing of the characeristics of the palm farmer in Nagari Air Hitam, Silaut Sub-district, Pesisir Selatan District. This kind of research is quantitative research. Population and sample inside this research is palm oil farmer in the Nagari Air Hitam Silaut Sub-district, Pesisir Selatan District. Data collection is done through observation and questionnaires. The research data were analyzed using percentage formula and liker scale. The result of this study show that: (1)The average of the farmland area is 0,5-2 hectare.(2) The average length of business for oil palm farmers is between 5-10 years.(3)The intensity of the counseling is low.(4) The use information sources to add knowledge is very low, the benefits of the latest sources of information are very low, and parties that provide information are also very low. (5) Famers do not cultivate a regularly. (6) The average farmer uses pesticide 2 liters/acre, the type of pesticide used is a gramason, the average farmer used pesticida twice a year.
\end{abstract}

Keyword: Characteristics a Farmer Palm Oil

\footnotetext{
${ }^{1}$ Mahasiswa Program Studi Pendidikan Geografi

${ }^{2}$ Dosen Jurusan Geografi Fakultas Ilmu Sosial Universitas Negeri Padang
} 
PENDAHULUAN

Indonesia dikenal sebagai negara agraris karena dianugrahi kekayaan alam yang melimpah.Selain itu alasan negara Indonesia disebut sebagai negara agraris karena mayoritas penduduknya bermata pencaharian sebagai petani atau bercocok tanam, oleh sebab itu sektor pertanian ataupun perkebunan memegang peran penting bagi pendapatan nasional, sumber pendapatan, juga sebagai lapangan pekerjaan.

Salah satu hasil perkebunan yang memegang peran penting dalam perekonomian Indonesia yaitu perkebunan kelapa sawit.Perkebunan kelapa sawit dibedakan manjadi dua kelompok yaitu perkebunan kelapa sawit plasma dan perkebunan kelapa sawit swadaya. Perkebunan petani plasma adalah masyarakat melakukan kerja sama dengan perusahaan dalam mengelola perkebunan kelapa sawit yang berada di sekitar lokasi perkebunan.

Sedangkan perkebunan swadaya adalah perkebunan yang diolah sendiri oleh petani tanpa ada bantuan dari pihak lain. Biasanya petani pola swadaya sering mengalami masalah pembiayaan dan sulit untuk memperoleh informasi dan pengetahuan untuk menerpakan praktik pertanian yang baik.

Kemampuan petani dalam mengembangkan usaha taninya dapat dipengaruhi oleh karakteristik petani itu sendiri baik itu karakteristik internal maupun eksternal. Karakteristik secara umum adalah karakter atau gaya hidup seseorang yang berbeda dari yang lain.
Menurut Seokartawi (2000) mengatakan bahwa karakteristik internal yang dapat mempengaruhi usaha tani adalah umur, pendidikan, jumlah tanggungan keluarga lama usaha tani, luas lahan, dan kekosmopolitan. Karakteristik eksternal yang dapat mempengaruhi usaha tani diantaranya intensitas penyuluhan, ketepatan penyuluhan, keterjangkauan harga saprodi, ketersediaan saprodi, sumber informasi.

Seperti halnya di Nagari Air Hitam Kecamatan Silaut Kabupaten Pesisir Selatan dengan jumlah penduduk 421 KK, dimana mayoritas penduduknya bermata pencaharian sebagai petani kelapa sawit dan hasil dari perkebunan kelapa sawit itu menjadi sumber pendapatan utama penduduk Nagari Air Hitam.

Pola perkebunan yang dilakukan oleh petani kelapa sawit di Nagari Air Hitam mennggunakan pola swadaya yaitu tanpa ada kerjasama dengan pihak lain. Mayoritas penduduk di Nagari Air Hitam hanya mengandalkan hasil dari perkebunan kelapa sawit dan sangat jarang sekali yang memiliki usaha atau pekerjaan sampingan.

Permasalahan yang sering dialami oleh petani kelapa sawit di Nagari Air Hitam adalah menurunnya hasil panen kelapa sawit. Jika hasil panen menurun makan pendapatan petani akan menurun sehingga petani tidak dapat memenuhi kebutuhan sehari-hari mereka yang semakin hari semakin mahal. Hal inijuga akan berpengaruh pada kondisi sosial ekonomi di Nagari Air Hitam tersebut. 
Perkembangan perekonomian suatu daerah tidak berarti apa-apa tanpa ada manfaatnya yang dirasakan oleh penduduknya.Begitu juga dengan perkembangan perkebunan kelapa sawit du Nagari Air Hitam yang menjadi fokus utama adalah para petaninya.Seperti yang telah dijelaskan seblumnya bahwa keberhasilan usaha tani dapat dipengaruhi oleh karakteristik petani itu sendiri baik karaktersiktik internal maupun eksternal.

Berdasarkan penjelasan di atas maka penliti tertarik untuk melakukan penelitian tentang "Karakteristik Petani Kelapa Sawit di Nagari Air Hitam Kecamatan Silaut Kabupaten Pesisir Selatan”.

Karakteristik menurut Kamus Besar Bahasa Indonesia adalah sifatsifat kejiwaan atau budi pekerti yang membedakan seseorang dengan yang lain. Sedangkan menurut Budiyono (2005) karakteristik adalah ciri khas atau bentuk-bentuk, watak/karakter yang dimiliki setiap individu, corak tingkah laku, tanda khusus.

Menurut Marnala, dkk (2017)

luas penguasaan lahan pertanian merupakan sesuatu yang penting dalam proses produksi ataupun ussaha tani. Fadholi dalam Riawati, dkk (2016), terdapat 3 golongan petani berdasarkan luas tanahnya yaitu; 1) Golongan petani luas (>2 Ha), 2) golongan petani sedang $(0,5-2 \mathrm{Ha}), 3)$ golongan patani sempit (0,5 Ha).

Menurut Seokartawi (2000) pengalaman seseorang dalam berusaha tani berpengaruh dala menerima inovasi dari luar. Petani yang sudah lama berusaha tani akan lebih mudah dalam menerapkan inovasi dari pada petani pemula. Petani yang sudah lama berusaha tani akan lebih mudah menerapkan anjuran penyuluhan dan menerapkan teknologi.

Menurut Riawati, dkk (2016) intensias penyuluhan adalah jumlah pertemuan yang dilaksanakan oleh penyuluh dan dihadiri oleh petani atau kelompok tani, untuk tempat pertemuan dapat dilaksanakan di kediaman kelompok tani, balai desa, dan pondok pertemuan di lahan usaha tani.

Menurut statistik sarana pertanian (2017) sarana produksi dalam pertanian terdiri dari data benih, bibit, pupuk, pestisida, dan alat mesin pertanian.Pupuk memiliki peran penting dalam usaha tani karena dapat meningkatkan unsur hara dalam tanah, dan dapat meningktakan hasil produksi tanaman.

Penggunaan pestisida pada tanaman berfungsi untuk membasmi gulma dan penyakit.Dalam penggunaan pestisida harus sesuai dengan aturan penggunaan dan umur tanaman. Menurut Peraturan Menteri No. 107 Tahun mendefenisikan pestisida sebagai semua zat kimia dan bahan lain serta jasad renik dan virus yang dapat digunakan diantaranya untuk memeberantas hama dan penyakit, dan memberantas rerumputan. Sehingga pestisida memiliki peran penting dalam usaha tani karena dapat membantu melindungi tanaman dari berbagai penyakit dan pertumbuhan yang tidak diinginkan, sehingga tanaman dapat berkembang denga baik. 
Menurut UU No. 19 Tahun 2013 tentang perlindungan dan pemberdayaan petani mengartikan petani sebagai warga negara Indonesia perseorangan atau beserta keluarganya yang melakukan usaha tani dibidang tanaman pangan, hortikultura, perkebunan atau peternakan.

\section{METODE PENELITIAN}

Penelitian ini dilakukan di Nagari Air Hitam Kecamatan Silaut Kabupaten Pesisir Selatan.

Berdasarkan tujuan penelitian, maka penelitian ini adalah penelitian yang menggunakan metode deskriptif dengan pendekatan kuantitatif, yaitu penelitian yang berupaya menjelaskan dan menganalisis suatu masalah dan dalam pemecahannya menggunakan angka-angka, dan hasil akhirnyapun berupa angka-angka.

Jenis data dalam penelitian ini adalah data sekunder dan data primer. Data sekunder dalam penelitian ini adalah jumlah petani kelapa sawit yang ada di Nagari Air Hitam.Sedangkan data primer dalam penelitian ini adalah karakteristik petani kelapa sawit di Nagari Air Hitam. Teknik pengumpulan data dalam penelitian ini melalui teknik observasi dan angket.Teknik analisis data dalam penelitian ini menggunakan rumus skala likert dan persentase.

\section{HASIL DAN PEMBAHASAN}

Berdasarkan hasil penelitian di lapangan tentang karkateristik petani kelapa sawit di Nagari Air Hitam maka diperoleh data-data, dan informasi tentang tentang petani kelapa sawit bahwasanya mayoritas petani kelapa sawit di Nagari Air Hitam berjenis kelamin laki-laki, dengan usia 15-64 tahun dan tingkat pendidikan sebagian besar tamatan SD.

Informasi yang diperoleh tentang karkateristik petani kelapa sawit yaitu:

\section{Luas Lahan}

Maksud dari luas lahan adalah seberapa luas lahan petani yang ditanami kelapa sawit.

Luas lahan petani kelapa sawit di Nagari Air Hitam dapat dilihat pada tabel 1.

Tabel 1. Luas Lahan Petani Kelapa Sawit

\begin{tabular}{|c|c|c|c|c|}
\hline No & $\begin{array}{c}\text { Luas } \\
\text { Lahan } \\
\text { (Ha) }\end{array}$ & Kategori & Responden & $\mathbf{( \% )}$ \\
\hline 1 & 0,5 & Sempit & 6 & 13,6 \\
\hline 2 & $0,5-2$ & Sedang & 29 & 66 \\
\hline 3 & $\geq 2$ & Luas & 9 & 20,4 \\
\hline \multicolumn{3}{|c|}{ Jumlah } & $\mathbf{4 4}$ & $\mathbf{1 0 0}$ \\
\hline
\end{tabular}

Sumber: Pengolahan Data Primer (2018) 
Berdasarkan table 1 dapat disimpulkan bahwa sebagian besar luas lahan petani kelapa sawit di Nagari Air Hitam adalah 05-2 Ha, termasuk golongan sedang.

Sesuai dengan pendapat Fadholi dalam Riawati (2016) membagi luas lahan dalam tiga golongan yaitu: Golongan sempit $(0,5 \mathrm{Ha})$, golongan sedang (0,5-2 Ha), dan golongan luas (>2 Ha). Mayoritas status kepemilikan lahan petani kelapa sawit adalah lahan milik sendiri.Pengambilan hasil panen kelapa sawit dilakukan dua kali dalam sebulan.

Mayoritas hasil panen petani kelapa sawit adalah 0-5 Kwintal/Ha.Hasil produksi kelapa sawit petani di Nagari
Air Hitam dapat dikategorikan rendah karena maksimalnya rata-rata panen perkebunan kelapa sawit per hektarnya bisa mencapai 3 ton. Hal ini merujuk pada pendapat Nurhakim (2014) bahwa standar produksi kelapa sawit per hektar minimal $2000 \mathrm{Kg}$ dan maksimal 3000 $\mathrm{Kg}$. Sehingga dapat disimpulkan bahwa hasil panen petani kelapa sawit di Nagari Air Hitam masih tergolong rendah.

\section{Lama Usaha Tani}

Adalah lama respoden menjadi petani kelapa sawit mulai dari awal sampai saat penelitian dilakukan. Lama usaha petani kelapa sawit di Nagari Air Hitam dapat dilihat pada tabel 2 di bawah ini:

Tabel 2. Lama Usaha Tani Kelapa Sawit

\begin{tabular}{|c|c|c|c|}
\hline No & $\begin{array}{c}\text { Lama Usaha } \\
\text { (Tahun) }\end{array}$ & Responden & $(\boldsymbol{\%})$ \\
\hline 1 & $5-10$ & 23 & 52,3 \\
\hline 2 & $11-16$ & 9 & 20,4 \\
\hline 3 & $17-22$ & 12 & 27,3 \\
\hline 4 & $\geq 22$ & 0 & 0 \\
\hline \multicolumn{2}{|c|}{ Jumlah } & $\mathbf{4 4}$ & $\mathbf{1 0 0}$ \\
\hline
\end{tabular}

Sumber: Pengolahan Data Primer (2018)

Berdasarkan tabel di atas dapat disimpulkan bahwa rata-rata lama usaha tani petani kelapa sawit di Nagari Air Hitam adalah 11-16 tahun, lama usaha masih tergolong rendah.Sehingga masih membutuhkan pengetahuan baik dari penyuluhan maupun pihak lainnya.Sebagian besar petani kelapa sawit di Nagari Air Hitam tidak memiliki usaha atau pekerjaan sampingan.Petani hanya mengandalkan pendapatan mereka pada hasil perkebunan kelapa sawit.

\section{Intensitas Penyuluhan}

Intensitas penyuluhan adalah seberapa sering petani mendapatkan penyuluhan tentang pengelolaan perkebunan kelapa sawit. Berdasarkan hasil penelitian di lapangan maka informasi intensitas penyuluhan dapat dilihat pada tabel 3 di bawah ini: 
Tabel 3. Intensitas Penyuluhan di Nagari Air Hitam

\begin{tabular}{|c|c|c|c|c|c|}
\hline No & $\begin{array}{c}\text { Tingkat } \\
\text { Kehadiran }\end{array}$ & Skor & Responden & $\mathbf{( \% )}$ & Kategori \\
\hline 1 & Tingkat & 1 & 44 & 100 & SR \\
& kehadiran & 2 & 0 & 5 & $\mathrm{R}$ \\
& penyuluh & 3 & 0 & 0 & $\mathrm{CT}$ \\
& & 4 & 0 & 0 & $\mathrm{~T}$ \\
& & 5 & 0 & 0 & $\mathrm{ST}$ \\
\hline 2 & Memanfaatka & 1 & 44 & 100 & $\mathrm{SR}$ \\
& n pertemuan & 2 & 0 & 0 & $\mathrm{R}$ \\
& untuk saling & 3 & 0 & 0 & $\mathrm{CT}$ \\
& berdiskusi & 4 & 0 & 0 & $\mathrm{~T}$ \\
& & 5 & 0 & 0 & $\mathrm{ST}$ \\
\hline 3 & Manfaat & 1 & 44 & 100 & $\mathrm{SR}$ \\
& penyuluhan & 2 & 0 & 0 & $\mathrm{R}$ \\
& & 3 & 0 & 0 & $\mathrm{CT}$ \\
& & 4 & 0 & 0 & $\mathrm{~T}$ \\
& & 5 & 0 & 0 & $\mathrm{ST}$ \\
\hline
\end{tabular}

Sumber: Pengolahan Data Primer (2018)

Dari tabel di atas dapat disimpulkan bahwa Dari tabel di atas dapat dilihat bahwa tingkat kehadiran penyuluh di Nagari Air Hitam Kecamatan Silaut sangat rendah, berdasarkan informasi yang didapatkan bahwa hanya pernah ada pemberian informasi sekali saja yang diterima oleh petani dan itupun hanya dua orang yang pernah mendapatkannya.

Sehingga dapat disimpulkan bahwa petani kelapa sawit di Nagari Air Hitam tidak pernah mendapatkan punyuluhan dan juga tidak pernah memanfaatkan pertemuan untuk saling berdiskusi karna tidak adanya penyuluhan serta petani juga tidak pernah merasakan bagaimana manfaat dari penyuluhuna itu sendiri.

Sesuai dengan pendapat Marnala, dkk (2017) mengatakan penyuluhan pertanian lapangan merupakan agen perubahan yang langsung berhubungan dengan petani.Sehingga dengan adanya penyuluhan yang dilakukan diharapkan dapat membawa perubahan yang lebih baik bagi untuk petani.

\section{Jumlah Sumber Informasi}

Jumlah sumber informasi adalah banyaknya informasi yang diterima oleh petani dalam melakukan usaha tani. Informasi tentang jumlah informasi dapat dilihat pada tabel 4.

Table 4. Jumlah Sumber Informasi

\begin{tabular}{|c|c|c|c|c|c|}
\hline No & $\begin{array}{c}\text { Jumlah } \\
\text { Sumber } \\
\text { Informasi }\end{array}$ & Skor & Responden & $(\%)$ & Kategori \\
\hline 1 & $\begin{array}{l}\text { Memanfa } \\
\text { atkan } \\
\text { sumber } \\
\text { informasi } \\
\text { untuk } \\
\text { memperlu } \\
\text { as } \\
\text { pengetahu } \\
\text { an }\end{array}$ & $\begin{array}{l}1 \\
2 \\
3 \\
4 \\
5\end{array}$ & $\begin{array}{l}29 \\
15 \\
0 \\
0 \\
0\end{array}$ & $\begin{array}{c}66 \\
34 \\
0 \\
0 \\
0\end{array}$ & $\begin{array}{l}\text { SR } \\
\text { R } \\
\text { CT } \\
\text { T } \\
\text { ST }\end{array}$ \\
\hline 2 & $\begin{array}{c}\text { Manfaat } \\
\text { sumber } \\
\text { informasi } \\
\text { terbaru } \\
\text { terhadap } \\
\text { usahatani }\end{array}$ & $\begin{array}{l}1 \\
2 \\
3 \\
4 \\
5\end{array}$ & $\begin{array}{l}33 \\
11 \\
0 \\
0 \\
0\end{array}$ & $\begin{array}{c}75 \\
25 \\
0 \\
0 \\
0\end{array}$ & $\begin{array}{c}\text { SR } \\
\text { R } \\
\text { CT } \\
\text { T } \\
\text { ST }\end{array}$ \\
\hline 3 & $\begin{array}{c}\text { Pihak } \\
\text { yang } \\
\text { memberik } \\
\text { an } \\
\text { informasi }\end{array}$ & $\begin{array}{l}1 \\
2 \\
3 \\
4 \\
5\end{array}$ & $\begin{array}{c}42 \\
2 \\
0 \\
0 \\
0\end{array}$ & $\begin{array}{c}95 \\
5 \\
0 \\
0 \\
0\end{array}$ & $\begin{array}{c}\text { SR } \\
\text { R } \\
\text { CT } \\
\text { T } \\
\text { ST }\end{array}$ \\
\hline
\end{tabular}

Sumber: Pengolahan Data Primer (2018) 
Dari tabel di atas dapat dilihat bahwa pada indikator satu sebagian besar petani kelapa sawit di Nagari Air Hitam tidak memanfaatkan sumber informasi untuk menambah pengetahuan tentang pengolahan perkebunan kelapa sawit.

Pada indikator kedua manfaat sumber informasi terbaru sangat rendah dirasakan oleh petani kealpa sawit, karena sebagian besar petani kelapa sawit tidak memanfaatkan sumber informasi untuk menambah pengetahuan.
Pada indikator ketiga berdasarkan tabel di atas diketahui bahwa pihak yang memberikan informasi sangat rendah. Dari 44 responden yang diteliti hanya dua orang yang pernah mendapatkan informasi dari pihak lain dan itupun hanya sekali.

\section{Penggunaan Pupuk}

a. Kegiatan Pemupukan

Bertujuan untuk mengetahui seberapa sering petani melakukan pemupukan untuk perkebunan kelapa sawit yang mereka miliki. Kegiatan pemupukan petani kelapa sawit dapat dilihat pada tabel 5 .

Tabel 5. Penggunaan Pupuk Petani Kelapa Sawit

\begin{tabular}{|c|c|c|c|}
\hline No & $\begin{array}{c}\text { Penggunaan } \\
\text { Pupuk/Tahun }\end{array}$ & Responden & $\mathbf{( \% )}$ \\
\hline 1 & $\begin{array}{c}\text { Tidak Melakukan } \\
\text { Pemupukan }\end{array}$ & 10 & 54,55 \\
\hline 2 & 1 & 17 & 22,73 \\
\hline 3 & 2 & 14 & 15,9 \\
\hline 4 & $\geq 2$ & 3 & 6,82 \\
\hline \multicolumn{2}{|c|}{ Jumlah } & $\mathbf{4 4}$ & $\mathbf{1 0 0}$ \\
\hline
\end{tabular}

Sumber: Pengolahan Data Primer (2018)

Berdasarkan tabel 5 dapat disimpulkan bahwa mayoritas petani kelapa sawit di Nagari Air Hitam tidak melakukan pemupukan secara rutin.Kurangnya pupuk dapat berpengaruh terhadap hasil produksi kelapa sawit. Seperti yang dikemukakan oleh Direktur Utama Pupuk Indonesia yaitu Idat dalam Asep (2017) yang mengatakan bahwa, pupuk merupakan salah satu sarana produksi yang menentukan produksi dan produktivitas komoditas pertanian, juga berperan penting dalam menjaga stabilitas ketahanan pangan nasional.

Sehingga dapat disimpulkan bahwa pupuk sangat penting dalam usaha tani baik itu usaha tani kelapa sawit maupun usaha tani lainnya. Penggunaan pupuk pada tanaman dapat meningkatkan hasil produktivitas tanaman, sehingga dengan kurangnya pemupukan akan membuat hasil produksi akan menurun.

Berdasarkan hal tersebut dapat disimpulkan bahwa salah satu penyebab menurunnya hasil produksi kelapa sawit di Nagari Air Hitam karena kurangnya pemberian pupuk oleh petani terhadapa perkebunan kelapa sawitmereka.

\section{b. Jenis Pupuk}

Jenis pupuk yang digunakan oleh petani bisa berbeda-beda. Berdasarkan penelitian di lapangan diperoleh data jenis pupuk yang digunakan petani kelapa sawit di Nagari Air Hitam dapat dilihat pada tabel 6 . 
Tabel 6. Jenis Pupuk yang digunakan Petani Kelapa Sawit

\begin{tabular}{|c|c|}
\hline No & Jenis Pupuk \\
\hline 1 & Kcl \\
\hline 2 & Urea \\
\hline 3 & Npk \\
\hline 4 & Abu Janjang \\
\hline 5 & Poska \\
\hline 6 & Mutiara \\
\hline 7 & Granular \\
\hline 8 & Abu jajang \\
\hline 9 & Sp 36 \\
\hline 10 & Mahkota \\
\hline
\end{tabular}

Sumber: Pengolahan Data Primer (2018)

Berdasarkan tabel diatas dapat simpulkan bahwa ada 10 jenis pupuk yang digunakan oleh petani kelapa sawit di Nagari Air Hitam.

c. Jumlah jenis pupuk yang digunakan

Jumlah jenis pupuk yang digunakan adalah untuk melihat berapa jenis pupuk pupuk yang digunakan oleh setiap petanin dalam melakukan pumupukan. Jumlah jenis pupuk yang digunakan dapat dilihat pada tabel 7 .

Table 7. Jumlah Jenis Pupuk yang digunakan

\begin{tabular}{|c|c|c|c|}
\hline No & $\begin{array}{c}\text { Jumlah } \\
\text { jenis } \\
\text { pupuk }\end{array}$ & Responden & (\%) \\
\hline 1 & 4 & 5 & 15 \\
\hline 2 & 3 & 10 & 29 \\
\hline 3 & 2 & 12 & 35 \\
\hline 4 & 1 & 7 & 21 \\
\hline \multicolumn{2}{|c|}{ Jumlah } & $\mathbf{3 4}$ & $\mathbf{1 0 0}$ \\
\hline
\end{tabular}

Sumber: Pengolahan Data Primer (2018)

Dari tabel di atas dapat dilihat bahwa dari 34 responden yang ada 12 orang menggunakan dua jenis pupuk untuk melakukan pumupukan.

\section{d. Kendala Dalam Pemupukan}

Kendala yang dialami petani dalam pemupukan adalah ketersediaan pupuk yang terbatas dan mahalnya harga pupuk.Hal itu yang menyebabkan petani jarang melakukan pumupukan.

\section{Penggunaan Pestisida}

a. Perawatan Gulma

Gulma yang terdapat pada tanaman kelapa sawit adalah berupa jenis rerumputan liar, apabila tidak tidak dibersihkan dapat mengganggu perkembangan tanaman kelapa sawit. Perawatan gulma dapat dilihat pada tabel 8 .

Tabel 8. Jenis Perawatan Gulma Petani Kelapa Sawit

\begin{tabular}{|c|c|c|c|}
\hline No & $\begin{array}{c}\text { Jenis } \\
\text { Perawatan }\end{array}$ & Responden & $(\boldsymbol{\%})$ \\
\hline 1 & Semprot & 44 & 100 \\
\hline 2 & Lainnya & 0 & 0 \\
\hline \multicolumn{2}{|c|}{ Jumlah } & $\mathbf{4 4}$ & $\mathbf{1 0 0}$ \\
\hline
\end{tabular}

Sumber: Pengolahan Data Primer (2018)

Berdasarkan tabel di atas dapat dilihat bahwa petani kelapa sawit di Nagari Air Hitam melakukan perawatan gulma dengan cara penyomprotan yaitu menggunakan pestisida. Penggunaan pestisida dapat membantu membunuh gulma dan penyakit yang ada pada tanaman.

Sesuai dengan Peranturan Menteri Pertanian No. 107 Tahun 2014 mendefenisikan bahwa pestisida adalah zat kimia dan bahan lain serta jasad renik dan virus yang dapat digunakan diantaranya untuk memberantas atau mencegah hamahama dan penayakit yang merusak tanaman, bagian-bagian tanaman atau hasil pertanian, memberantas rerumputan, dan mematikan daun dan mencegah pertumbuhan yang tidak diingingkan.

b. Kebutuhan Pestisida

Setiap petani memiliki kebutuhan pestisida yang berbeda-beda. Kebutuhan pestisida petani kelapa sawit dapat dilihat pada tabel 9. 
Tabel 9. Kebutuhan Pestisida Petani

\begin{tabular}{|c|c|c|c|}
\hline \multicolumn{4}{|c|}{ Kelapa Sawit } \\
\hline No & $\begin{array}{c}\text { Kebutuhan } \\
\text { Pestisida } \\
\text { (Liter)/Ha }\end{array}$ & Responden & $(\%)$ \\
\hline 1 & $0,5-1$ & 15 & 34,09 \\
\hline 2 & 2 & 26 & 59,09 \\
\hline 3 & $\geq 2$ & 3 & 6,82 \\
\hline & Jumlah & 44 & 100 \\
\hline
\end{tabular}

Sumber: Pengolahan Data Primer (2018)

Berdasarkan tabel di atas dapat dilihat bahwa sebagian besar petani kelapa sawit menggunakan pestisida 2 liter/hektar.

c. Jenis Pestisida

Jenis pestisida yang digunakan setiap petani kelapa sawit berbeda-beda. Jjenis pestisida yang digunakan petani kelapa sawit dapat dilihat pada tabel 10.

Tabel 10. Jenis Pestisida yang Digunakan Petani Kelapa Sawit

\begin{tabular}{|c|l|c|c|}
\hline No & $\begin{array}{c}\text { Jenis } \\
\text { Pestisida }\end{array}$ & Responden & $\mathbf{( \% )}$ \\
\hline 1 & Gramason & 39 & 88,64 \\
\hline 2 & Supretox & 5 & 11,36 \\
\hline 3 & Lainnya & 0 & 0 \\
\hline \multicolumn{2}{|c|}{ Jumlah } & $\mathbf{4 4}$ & $\mathbf{1 0 0}$ \\
\hline
\end{tabular}

Sumber: Pengolahan Data Primer (2018)

Berdasarkan tabel di atas dapat dilihat bahwa sebagian besar petani kelapa sawit di Nagari Air Hitam menggunakan jenis pestisida yang digunakan adalah gramason.

d. Penggunaan Pestisida/Tahun

Penggunaan pestisida setiap petani tentu berbeda-beda sesuai dengan kebutuhan perkebunan masingmassing. Informasi penggunaan pestisida disajikan pada tabel 11 .

Tabel 11. Penggunaan Pestisida/Tahun Petani Kelapa Sawit

\begin{tabular}{|c|c|c|c|}
\hline No & $\begin{array}{l}\text { Penggunaan } \\
\text { /Tahun }\end{array}$ & Responden & $\mathbf{( \% )}$ \\
\hline 1 & 1 Kali & 15 & 34,09 \\
\hline 2 & 2 Kali & 26 & 59,09 \\
\hline 3 & $\geq 2$ Kali & 3 & 6,82 \\
\hline \multicolumn{2}{|c|}{ Jumlah } & $\mathbf{4 8}$ & $\mathbf{1 0 0}$ \\
\hline
\end{tabular}

Sumber:Pengolahan Data Primer (2018)

\section{Kesimpulan}

Berdasarkan hasil penelitian di lapangan tentang karakteristik petani kelapa sawit di Nagari Air Hitam Kecamatan Silaut Kabupaten Pesisir Selatan dapat disimpulkan beberapa hal yaitu:

Rata-rata luas lahan petani kelapa sawit di Nagari Air Hitam adalah antara 0,5-2 hektar, termasuk luas lahan sedang. Hasil panen rata-rata petani kelapa sawit adalah 0-5 Kwintal/hektar, hasil panen termasuk rendah.

Rata-rata lama usaha tani kelapa sawit di Nagari Air Hitam adalah antara 5-10 tahun, lama usaha tergolong rendah.Sebagian besar petani kelapa sawit tidak memiliki usaha atau pekerjaan sampingan.

Intensitas penyuluhan di Nagari Air Hitam tergolong sangat rendah karena dari 44 responden yang diteliti tidak pernah menerima penyuluhan, tetapi hanya pernah mendapatkan informasi dan hanya satu kali.

Sebagian besar petani kelapa sawit di Nagari Air Hitam tidak memanfaatkan sumber informasi terbaru untuk menambah pengetahuan, sehingga manfaat sumber informasi terbari tidak dirasakan oleh petani kelapa sawit.Pihak yang memberikan informasi terbaru di Nagari Air Hitam juga sangat rendah.

Kegiatan pemupukan oleh petani kelapa sawit di Nagari Air Hitam masih tergolong rendah. Berdasarkan hasil penelitian dari 44 responden yang ada hanya 20 responden yang melakukan pemupukan dalam jangka waktu setahun, dan 24 responden lainnya 
melakukan pemupukan dalam jangka waktu dua atau tiga tahun sekali. Ratarata petani kelapa sawit menggunakan jenis pupuk $\mathrm{Kcl}$ untuk pemupukan perkebunan kelapa sawitnya.

Rata-rata petani menggunakan 2 liter pestisida/hektar untuk perawatan gulma.Jenis pestisida yang digunakan adalah garamson.Mayoritas petani menggunakan pestisida dua kali dalam setahun.

\section{Saran}

Adapun saran yang dapat penulis berikan adalah sebagai berikut:

1. Dari segi pemerintah sebaiknya meningkatkan lagi kegiatan penyuluhan untuk petani kelapa sawit di Nagari Air Hitam, agar petani kelapa sawit mendapatkan informasi dan pengetahuan tentang pengelolaan perkebunan kelapa sawit yang baik agar hasil produktivitas hasil panen dapat meningkat.

2. Sebaiknya petani kelapa sawit di Nagari Air Hitam lebih meningkatkan lagi kegiatan pemupukan untuk perkebunan kelapa sawit mereka karena, pemupukan dapat meningkatkan produktivitas buah kelapa sawit dan membantu perkembangan tanaman kelapa sawit.

3. Sebaiknya petani kelapa sawit lebih aktif lagi untuk mencari informasi atau pengetahuan tentang meningkatkan produktivitas kelapa sawit, karena penyuluhan dapat dikatakan tidak ada di Nagari Air Hitam ini.

\section{DAFTAR PUSTAKA}

Asep, Budiman. 2017 November 17. Bahaya Pupuk Palsu, Produktivitas Pertanian Bisa Menurun.

Budiyono.2005. Kamus Ilmiah Populer Internasional. Surabaya: ALUMNI Surabaya.

Marnala, Juvan, Roza Yulida ,\& Eri Sayamar. 2017. Karakteristik Petani Padi Peserta Program Upaya Khusus Padi Jagung Kedelai (UPSUS PAJALE) di Desa Bunga Raya Kecamatan Bungan Raya Kabupaten Siak: Karakteristik Petani Padi Peserta Progra. 4 (1).

Nurhakim, Y. I. 2014. Perkebunan Kelapa Saawit Cepat Panen. Infra Pustaka. Jakarta.

Peraturan Menteri Pertanian Republik Indonesia Nomor 107/Permentan/SR.140/9/2014. Tentang Pengawasan Pestisida.

Riawati, Rosnita, \& Roza Yulida.2016. Karaktersitik Internaal dan Karakteristik Eksternal Petani Kelapa Sawit di Desa Buluh Rampai Kecamatan Seberida Kabupaten Indragiri Hulu.Karakteristik Internal dan Karakteristik.3 (2).

Seokartawi. 2000. Pengantar Agroindistri. Rajagrafindo Pustaka. Jakarta.

Kementrian Pertanian Republik Indonesia. Statistik Sarana Pertanian. 2017. http://epublikasi.setjen.pertanian.go .id/arsip-perstatistikan/180statistik/statistik-prasarana-dansarana-pertanian/524-statistiksarana-pertanian-tahun-2017

Sudarminto Setyo Yuwono. 2015 September 29. Tanaman Kelapa Sawit.

Undang-Undang Republik Indonesia Nomor 32 Tahun 2009 tentang 
Perlindungan dan Pengelolaan Lingkungan Hidup.

Undang-Undang Republik Indonesia Nomor 19 Tahun 2013 tentang Perlindungan dan Pemberdayaan petani. 